\title{
Possible objections to a philosophical approach to ancient Israelite religion: A critical refutation
}

Author:
Jacobus W. Gericke'
Affiliation:
'Faculty of Humanities,
North-West University,
Vaal Triangle Campus,
South Africa
Correspondence to:
Jaco Gericke
Email:
21609268@nwu.ac.za
Postal address:
22 Dromedaris, Toon
van den Heever Street,
Sasolburg 1947, South Africa
Dates:
Received: 19 May 2010
Accepted: 29 Nov. 2010
Published: 24 June 2011
How to cite this article:
Gericke, J.W., 2011,
'Possible objections to a
philosophical approach to
ancient Israelite religion:
A critical refutation',
HTS Teologiese Studies/
Theological Studies
67(3), Art. \#859, 7 pages.
doi:10.4102/hts.v67i3.859

(C) 2011. The Authors. Licensee: AOSIS OpenJournals. This work is licensed under the Creative Commons Attribution License.
There exists a certain consensus amongst biblical scholars that involving philosophy in the attempt to understand ancient Israelite religion is hermeneutically fallacious. A philosophical approach to ancient Yahwism is considered out of place, given the non-philosophical nature of the Hebrew Bible, the normative concerns of philosophy and the historical agenda of biblical scholarship. In this article, however, the author attempted to show why none of the traditional objections should be considered as devastating as they were once thought to be.

\section{Introduction}

There is a long tradition in biblical interpretation that considers philosophy a distortion of biblical religion (see Charlesworth 2002:87). The usual suspects include inter alia:

- Paul's derision of Greek wisdom (1 Cor 2)

- the pseudo-Pauline warning to believers not to let themselves be spoiled by philosophy (Col 2:8)

- Tertullian's claim that Athens and Jerusalem have nothing in common

- Thomas Aquinas' distinction between truths from reason and revelation

- the later Martin Luther's dismissal of Aristotelian metaphysics and logic

- Benedict de Spinoza's denial that philosophy and the Bible can peacefully co-exist

- Blaise Pascal's distinction between the God of Abraham, Isaac and Jacob and the God of the philosophers

- Johan Philip Gabler's distinction between biblical and dogmatic theology

- Johann Gottfried Herder's stereotype of Hebrew poetry

- Karl Barth and his followers' aversion to natural theology

- Walter Eichrodt's view that extra-biblical concepts and categories were a-priori distortive

- the Biblical Theology Movement concept of 'Hebrew thought' (from Boman) and so forth (see Barr 1999:146-171).

Many more instances of influential antiphilosophical sentiment can be noted, but these should suffice to reveal the grain against which this article is writing. The cumulative influence of such anti-philosophical sentiments in the history of interpretation has led to a state of affairs where some biblical theologians find it necessary to point out that philosophy has no place in biblical scholarship on the level of exegesis. To be sure, some biblical scholars dabble in applying the insights from the philosophy of science, philosophy of literature, social philosophy and postmodern theory to hermeneutics and exegesis. However, in the study of ancient Yahwism the philosophy of religion is not utilised in any descriptive capacity by mainstream biblical theologians and there is no official form of philosophical criticism in exegesis. As Barr (1999) notes:

It would be difficult to exaggerate the degree of alienation that the average biblical scholar has felt in relation to the work of disciplines like philosophical theology or philosophy of religion. Their modes of discussion and decision seem to him or her remote and unreal. The questions they discuss and the criteria they apply seem to be contrived and artificial, and the world of discourse in which they move seems to be quite a different world from the world of the Bible, to which the biblical scholar feels he has a sort of direct and empirical access.

(Barr 1999:146)

Therefore, anyone who wonders why a philosophical account of ancient Israelite religion is missing must surely be ignorant of the painful lessons that two centuries of biblical criticism and hermeneutic reflection has taught us. In the confines of this article, I begged to differ. In the discussion to follow, I intended to expose some of the popular objections to a philosophical approach and their respective fallacies. This was done in order to prepare the way for rethinking the supposed validity of antiphilosophical sentiment in the study of ancient Israelite religion.

\section{Fallacies in possible objections}

In order to prevent latent anti-philosophical sentiment in biblical scholarship from becoming an obstacle in the communication of the new ideas to follow, it is of paramount importance to 
anticipate possible objections of involving philosophy of religion in the study of the Hebrew Bible. On this point, three categories of possible critique may be distinguished:

- objections appealing to the nature of the Hebrew Bible

- objections appealing to the nature of philosophy

- objections appealing to the nature of Biblical scholarship.

In this section, I intended to show cognisance of and reply to over two dozen possible objections to a philosophical analysis of the beliefs, concepts and practices of ancient Israelite religion.

The first objection against a philosophical approach might be based on the belief that the Hebrew Bible contains no philosophy of religion. Thus, according to Gerhard von Rad (1962:12): 'Israel had no philosophical conception of God'.

Erhard Gerstenberger (2002:245) reinforces the point: 'Yhwh became not only the personal God but the exclusive Lord of the whole world, and this view did not develop out of philosophical considerations.' [Author's emphasis]

However, the claim that a philosophical approach to ancient Israelite religion is distortive because there is no philosophy in the Hebrew Bible involves a clear-cut case of non-sequitur reasoning. It simply does not follow that philosophical inquiry requires the object of its analysis to be philosophical in nature itself. As the philosophical theologian Morris (2002) reminds us:

The Bible is not a textbook of philosophical theology. Its texts on God are thus neither as complete nor as specific as the philosophical theologian needs in order to be able to answer fully his conceptual, or philosophical questions. Are these questions then illegitimate from a biblical standpoint? I see no reason to think so at all. From the fact that the biblical documents, written as they were to deal with burning practical questions of the greatest personal significance, do not address all the possible philosophical questions, which can also, in their own way, be of the greatest personal significance, it does not follow at all that these more theoretical questions are illegitimate.

(Morris 2002:31 [Author's emphasis])

Indeed not. For philosophical analysis does not require the object of its inquiry to be philosophical in nature itself in order to clarify its meaning from a philosophical perspective. Moreover, although not overtly philosophical in the sense used by the developed world, the Hebrew Bible does contain taken-for-granted metaphysical, epistemological and moral assumptions that can be described in philosophical terms. A philosophical approach to Israelite religion is therefore possible, not because the Hebrew Bible is philosophy, but because it is religion.

The second objection involves the often heard claim that philosophical questions are out of place and anachronistic because the biblical authors show no such concerns. This seems to be the gist implicit in the following entry of a popular Bible Encyclopaedia:

There is no speculative philosophy in the Old Testament, nor any certain trace of its influence. Its writers and actors never set themselves to pursue knowledge in the abstract and for its own sake. They always wrought for moral purposes. But moral activity proceeds on the intellectual presuppositions and interpretations of the experiences within which it acts. Hence, we find in the Old Testament accounts of the origin and course of nature, a philosophy of history and its institutions, and interpretations of men's moral and religious experiences. They all center in God, issue from His sovereign will, and express the realization of His purpose of righteousness in the world.

(Orr, n.d.)

The same assumption, that one should stick to the concerns of the biblical authors themselves, is found in the words of Barton (1992):

The study of Hebrew Bible ethics has sometimes suffered from an unwillingness on the part of scholars to contemplate 'philosophical' questions at all, on the grounds that people of ancient Israel simply were not interested in, or could not have understood, questions of such a kind. A case could undoubtably be made in favour of such a belief but it needs to be made: it should not be asserted as though it were obvious.

(Barton 1992:20)

The main problem with any objection against a philosophical approach to Israelite religion that appeals to the concerns of the authors, is that it tends to operate with double standards. This soon becomes apparent when one realises that all our concerns are by default, if not by definition, anachronistic (they are ours). For example, none of the biblical authors bothered with the kind of questions that biblical scholars ask when engaged in linguistics, historical criticism, literary criticism, sociology or theology. Yet if this objection was consistently incorporated into biblical hermeneutics (itself an anachronistic cluster of concerns), it would follow that none of the traditional and popular approaches to the Hebrew Bible are hermeneutically valid either. So why are they tolerated? Eventually, philosophical concerns per se are no more anachronistic than any other contemporary concerns and the problem is not being anachronistic, but lies with distortions of meaning.

The third objection points to the possession of philosophical assumptions as somehow an obstacle to understanding. When one wishes to show what is wrong in another's interpretation, one simply accuses them of being blind to their philosophical presuppositions. But is this really a valid objection? No, because on the one hand, philosophical assumptions are omnipresent, as Barr (1999:168; see Murphy 1996) notes with reference to historical criticism: Biblical theologians have theological presuppositions, but they (like historians) have philosophical presuppositions as well.

All languages, including those in which every Old Testament theology ever written, contain some implicit folk-philosophy. Biblical theologians and their work are riddled with the folkphilosophical assumptions of the developed world and their ignorance of this does not make it one whit less. James Barr, therefore, rightly observed that those biblical scholars who dismiss philosophy on accounts of its alleged concerns with systematic thinking are not leaving philosophy behind at all. 
They have simply exchanged a stereotype for the latest antisystematic variety of existentialist and ordinary language philosophical concerns, whether they realise it or not (Barr 1999:168).

On the other hand, as with concerns, it is not so much the fact that our assumptions are also philosophical, but rather that these presuppositions might lead to a distortion of the textual contents. Thus, the problem lies not with philosophical assumptions, but perhaps with philosophical-theological presumptions. This nuanced way of thinking was something many subsequent theologians failed to appreciate, despite lip service to Barr's ideas. The fact is, precisely in order to avoid reading our own distortive, anachronistic, philosophical assumptions into the text, we actually need more (not less) philosophical clarification of the Hebrew Bible's own philosophical assumptions. This means that a philosophical account is not only not necessarily distortive, it is in fact hermeneutically required as part of a comprehensive historical approach to prevent philosophical eisegesis!

In the scholarly study of religion, it is taken for granted that linguistic, literary, historical, anthropological, sociological, psychological and theological perspectives are not in themselves sufficient for a holistic approach to religious phenomena (see Connolly 1999). As Taliaferro (2006:123) notes, if the goal is a comprehensive understanding of a given religion, the inquiries are incomplete if not supplemented by a philosophical approach.

The study of religion, to be complete, needs to address basic philosophical questions about what exists (metaphysics), what can be known (epistemology) and what is valuable (value theory and ethics). Philosophy is hard to avoid. Even radical dismissal of philosophy involves a philosophy.

In other words, it is impossible to understand the fundamental structures of the conceptual content in any religion without a clarification of its metaphysical, epistemological, moral and logical assumptions related to loci on the agenda of philosophy of religion. One cannot really start to appreciate the intricacies of any body of religious discourse unless one has discerned what it takes for granted regarding:

- the nature of religion

- religious language

- revelation

- religious experience

- the nature and existence of the Deity

- the relation between religion and morality

- the relation between religion and science

- religious pluralism, etcetera.

It hardly matters whether the religion in question is itself philosophical in its modes of expression, given that all ordinary religious discourse contains these assumptions. Unless we can come to terms with what went without saying in ancient Israelite worldviews, we have not understood the most elementary and basic presuppositions that explain why Yahwism was the ways it was, or why it was at all.
The fourth objection goes further still and holds that philosophical categories are distortive, because they are forced onto the discourse from the outside, rather than having been taken from the biblical context itself. This was Eichrodt's main objection to the use of extra-biblical categories in biblical theology. Since then, we find the sentiment expressed quite often that insists on sticking to intra-biblical frames of reference, as Preuss (1996) noted:

While there are inferences that may be drawn from the Old Testament's understanding of the nature of God, one should be careful about the use of later philosophical, theological categories of thought to set forth the Old Testament's view of reality.

(Preuss 1996:239)

Moreover, according to Brueggemann (1997:70): 'The Old Testament does not readily conform to ... the categories of any Hellenistic perennial philosophy'.

Thus, for many biblical scholars, the transposition (or transmutation) of the Hebrew Bible into the categories of Greek philosophy was a very bad thing. Moreover, the entire history of philosophy tended to be seen along the stereotype of Aristotle and Plato. The fallacy in this line of thought, however, was aptly pointed out by Thiselton (1980:3), who suggested that the problem did not lie with philosophical categories per se, but with the tendency to opt for poorly chosen ones. He mentions James Barr, who compared 'purist' or 'internalist' perspectives with externalist ones, arguing that the fundamental error in purist thinking is the supposition that by taking an internal perspective we somehow guard against error (Barr 1966:171-192). In discussing the problematic opposition of Hebraic and Greek thought in the question of distinctiveness, Barr (1966:40) already recognised the fact that the issue is not between philosophy and theology but between a proper historical-cultural study and an unhistorical use of philosophical categories'.

Barr thus realises (unlike many of his contemporaries) that the problem with philosophy does not lie with the use of anachronistic philosophical categories per se, but rather with the uncritical and unhistorical superimposing of philosophical-theological frameworks on conceptual backgrounds in the Hebrew Bible, where they are distortive of metaphysical assumptions in the textual data (Barr 1966:34-64). In addition, one cannot know that a given set of philosophical categories is in fact distortive, unless one also actually does a form of comparative philosophy (see Thiselton 1980:3-4). Therefore, involving the wrong philosophical categories will be distortive, saying in the end more about one's choice of philosophical categories than the validity of using philosophical categories per se.

The fifth objection follows from the fourth and concerns the fact that philosophy works with extra-biblical concepts and thus, with a meta-language that is superimposed on the text's own vocabulary. Again, however, the argument fails because philosophy of religion is no more 'meta-language' than a history or sociology of religion, as Smith (2008) recognised: 
First order discourse is discourse expressed in religious experience, such as prayer; second order discourse involves discourse representing intellectual reflection about the contents of that experience, as in theology, or philosophy of religion, or history of religion or comparative religion.

(Smith 2008:18)

The fact is that terminology and jargon not explicitly attested in biblical Hebrew are not necessarily distortive. This is clear if we recall that biblical theologians are not bothered by the fact that words like:

- 'morphology'

- 'metaphor'

- 'rhetoric'

- 'narration'

- 'context'

- 'character'

- 'structure'

- 'history'

- 'redaction'

- 'gender'

- 'typology'

- 'monotheism'

- 'religion'

- 'theology'

- 'culture'

- 'morality'

- 'experience'

- 'hermeneutics' and so forth, are also examples of extrabiblical meta-language (see also Smith 2004:2).

Many of these terms are ultimately derived from early philosophical backgrounds and none of them are intra-biblical categories presented to us by the authors themselves. And yet, such terms are considered perfectly proper, which shows that double standards are operative, philosophy is singled out for exclusion and the real problem is not neologisms per se, but distortive extensions and presumptuous agendas.

The sixth objection represents a further specification of the previous ones and concerns the nature of the biblical language, which is prose and poetry filled with metaphor and myth therefore considered problematic for philosophical reflection. The argument is implicit in a remark by Carroll (1991):

Theology operates with abstract philosophical notions whereas much of the language in the Bible is highly metaphorical. In philosophical talk, God is abstract ... In biblical language, God is a character in a narrative, a player in a story.

(Carroll 1991:37)

If the aesthetic literary qualities of the Hebrew Bible are taken to be problematic for philosophy, the notion of what philosophy is and can be concerned with has been utterly oversimplified. Philosophy itself cannot be reduced to its scholastic-systematic or normative-contemporary varieties and included from the beginning a concern with literature, fiction or art. In fact, much of the standard jargon in biblical literary criticism (e.g. narrative, metaphor, rhetoric, myth, etc.) ultimately derive from early Greek philosophy (e.g., from Aristotle's poetics and rhetoric). Literary criticism itself was born in philosophical reflection.
The seventh possible objection concerns the assumption that the theological pluralism of the Hebrew Bible is unsuitable for doing philosophy. This idea was voiced, again, most eloquently by Carroll (1991) in a remark, the bottom line of which is that philosophical-theological reflection should be forgotten about:

Reflecting on what you read may not be as conducive to systematic theology as you might have wished. The book is too untidy, too sprawling and too boisterous to be domesticated and tamed by neat systems of thought. If you want neatness, then close the book and turn to theology. But if you can tolerate contradiction and contrariety, if you can handle hyperbolic drive and chaotic manipulation of metaphor, then the Bible will burn your mind. We humans have produced few things like it. Oh, and a final word of warning: 'the things you're likely to read in the Bible ... ain't necessarily so!'

(Carroll 1991:147)

One can agree with everything here, yet still question the assumption that pluralism is problematic for all philosophical reflection. After all, descriptive philosophy aimed at clarification has no problem in simply elucidating the nature of diachronic variation and synchronic variability. Because a descriptive philosophical analysis, as found in the analytic, phenomenological and comparative traditions in philosophy of religion, has nothing to do with the construction of a unified systematic normative philosophy of religion, the objection seems irrelevant. If this were the case, the Hebrew Bible would be immensely problematic, Theological pluralism in the Hebrew Bible should not present a problem, but instead is a given reality, the nature of which can and should be described and clarified in philosophical terms.

The eighth objection holds that philosophy is irrelevant in the sense that, even if it could be utilised in a hermeneutically legitimate manner, it cannot contribute to the kind of historical clarification of the meaning that biblical scholars are interested in. According to Barr (1999):

... philosophy does not seem to solve biblical questions. So much in biblical scholarship depends on knowledge of a different kind ... A knowledge of Kant will not enable the scholar to distinguish between the piel and hiphil of the Hebrew verb and a reading of Hume will not explain why the Greek versions of Jeremiah and Job are substantially shorter than the present Hebrew text.

(Barr 1999:146)

If this view is representative of the views of many biblical theologians, the fact of the matter is that it involves fallacies of irrelevance and oversimplification. It all depends on what one means by philosophy. To be sure, knowledge of Kant will not teach anyone Hebrew Grammar, but neither will knowledge of Von Rad for that matter, although he was a biblical scholar, for this was not the purpose of their writings. In the same way, a reading of Hume may not settle the problem of the differences in length between Hebrew and Greek versions of Job and Jeremiah, but neither will a reading of Barr, for that was not his concern.

The fact is that the value of a philosophical approach would lie in its concern with the metaphysical, epistemological, moral and other assumptions in the text. These assumptions 
are never spelled out by the authors but, as they are implicit in all language, are there nonetheless. They represent the foundational structure of meaning in the conceptual background, yet are bracketed in purely literary, historical or sociological approaches, the concerns of which lie elsewhere. Still, it cannot be doubted that without a clarification of what the Hebrew Bible took for granted about issues on the agenda in philosophy of religion, we have started to come to terms with the conceptual content of ancient Israelite religion. Meaning depends not only on historical and social context, but also on philosophical elements that went without saying. In this sense then, not only can philosophical clarification contribute to the understanding of the Hebrew Bible in ways that non-philosophical approaches cannot, it is also indispensable in any comprehensive inquiry into the meaning of Yahwistic beliefs, concepts and practices.

The ninth objection involves pointing out that philosophy is out of necessity concerned with normative claims (like systematic theology), whereas biblical scholarship has a purely historical and descriptive interest that is not philosophical at all. This idea is implicit in the work of Hasel, (1985) who reflects on the debate on the role of philosophy within biblical theology:

The biblical theologian neither takes the place of nor competes with the systematic theologian or dogmatician. The latter has and always will have to fulfill his own task in that he endeavors to use current philosophies as the basis for his primary themes and categories. For the systematic theologian, it is indeed appropriate to operate with philosophical categories because his foundations are on a base different from that of the biblical theologian. The biblical theologian draws his categories, themes, motifs and concepts from the biblical text itself. The biblical theologian stands in danger of surreptitiously introducing contemporary philosophy into his discipline. But he must be careful to guard himself against this temptation.

(Hasel 1985:119)

In response to this objection, then, the now familiar reply follows. Not all philosophy is interested in turning the object of its analysis into normative ideas about the way things are. Purely analytic and phenomenological descriptive philosophical approaches are available that offer the possibility of the historical clarification of the Hebrew Bible. Moreover, a closer look at what philosophers actually do in practice shows that much of their philosophical task is not concerned with putting normative claims on the table, but with clarifying ideas of the past in philosophical terms, which may not be overtly philosophical or systematically presented themselves. Students of ancient philosophy are used to historical philosophical research when exploring the likes of Plato and Aristotle in their own setting. They first seek to clarify even outdated ideas, using methods of conceptual and metaphysical investigation in order to determine what was being said when translated into philosophical language (Hebblethwaite 2005:8).

The tenth objection is related to the previous one. It involves the claim that biblical scholars cannot do philosophy of religion because philosophers assume nothing and bracket alleged instances of divine revelation to which they cannot appeal to, as they rely on the light of reason alone. This objection, whilst in itself correct about how natural theologians have often operated, involves a category mistake. Of course, if we were natural theologians, who assumed that the theological status of the Hebrew Bible is that of alleged divine revelation, then indeed the text would have to be bracketed in our philosophical inquiries. However, because we operate in the context of biblical scholarship, where the concept of revelation pertains not to the Hebrew Bible itself but to the extension of that concept to the worlds in the text, this objection fails. We are not using the Hebrew Bible to do philosophy of religion in the form of natural a/theology; we are utilising descriptive varieties of philosophy of religion to clarify the meaning of the biblical texts. There is a big difference between the two and neither can claim to be more philosophical than the other as two different philosophical agendas are in view.

The eleventh objection comes from continental philosophy and claims that philosophical theology is impossible after Kant (the end of metaphysics and the transcendental pretence) and the rise of historical consciousness (the loss of faith in discovering universal eternal truths about ultimate reality). Here again, the objection is presumptuous because our concern as biblical scholars is not God as noumenon, but representations of Deity in the Hebrew Bible. The critique is moreover invalid in the same sense as the previous objection; it fails to take cognisance of the possibility of a descriptive philosophy of religion and of the aim of a phenomenologically reductive approach, both of which were in fact born in recognition of Kant's ideas and the end of dogmatic theology. In sum then, this objection fails in as much as a philosophical approach to ancient Israelite religion need not be concerned with arriving at a theoretical understanding of any transcendent realm or God in re, but can simply be aimed at a better understanding of what the Hebrew Bible assumed about these matters, whether these assumptions are true or not.

The twelfth objection follows from the previous two and concerns the claim that biblical scholars are not philosophers. As Barr (1999) noted:

And in this respect the biblical scholar, at least in the English speaking world, has felt himself closer to the atmosphere of the church and the practical work of the average clergyman, who (it is supposed) is more anxious to get to grips with the Bible and its message than to discuss such apparently theoretical matters as being and becoming, the nature of knowledge, or the subjectobject relationship. Relief from the unrealities of philosophical theology has been an unquestionable part of the motivation of those attracted to biblical theology.

(Barr 1999:146-147)

Note that, in the course of his argument, Barr has shifted the goalposts. His reference to philosophical topics in the second-to-last sentence of the quoted section concerns issues in metaphysics and epistemology proper, whereas his last sentence makes a claim about philosophical theology. These disciplines are not identical. Moreover, none of them 
are irrelevant. To be sure, the topics in their philosophical contexts might seem dry to some biblical scholars, but the argument from disinterest or boredom is hardly a sufficient reason. Many scholars are bored by linguistic or historical approaches, which are not for that reason rendered dysfunctional or irrelevant. There is no reason why we cannot attempt to describe in philosophical terms what the texts took for granted about being and becoming, the subjectobject relationship, the nature of knowledge, and so on.

Another problem with this objection lies in its committing of the essentialist fallacy. We are not all only $x$, where $x$ refers to historians, literary-critics or theologians. The only essence in biblical scholarship lies in the object of study (the Hebrew Bible) and not in any approach to it. So there is no a-priori reason why Biblical scholars should be historians or sociologists of Israelite religion, rather than philosophers of Israelite religion. In fact, the objection is moreover rather a-historical because it overlooks the fact that for the most part of the history of biblical interpretation, many commentators were in fact also philosophers and had philosophical concerns. Philosophical readings actually have a long and proud history, going all the way back to the apocryphal literature and Philo. Our tradition as philosophers who practice philosophical exegesis is much older than historical, socio-literary and biblical-theological approaches.

The thirteenth objection suggests biblical scholars should leave philosophy to philosophers proper. Again, however, double standards are at work, readily apparent from the fact that we do not leave historical inquiries to historians proper or biblical theology to theologians proper. So why leave biblical philosophy to philosophers proper? Knierim (1995) actually articulates the manner in which a descriptive philosophical analysis of ancient Israelite religion may operate (the example he gives is the meaning of the concept 'God') and shrewdly anticipates the expected critique against his ideas as follows:

Someone may ask whether the reach into this dimension of the questions does not amount to a biblical philosophy or a philosophy of the biblical truth. Indeed! And what would be wrong with that? Would it not, while focusing on the Bible, be in contact with philosophy of religion and with philosophy in principle, as biblical philosophy's contribution to those fields? Would it not, together with these fields, be concerned with the questions of reality, world, facts, meanings, language and truth, including the Bible's own foci and position on these matters in each of the testaments?

(Knierim 1995:221)

Curiously, Knierim himself never actually wrote a philosophical theology of the Old Testament. Neither did he conceive of a philosophical approach as an independent discipline in biblical studies, aside from Old Testament theology. For Knierim, the utilisation of philosophy therefore seems to have been conceived of as having merely utility in explicating the metaphysical and epistemological assumptions in the biblical texts on the way to more constructive theological enterprises. Yet his positive assessment of philosophical reflection was a sign of the times and a much-needed corrective to the popular misconception that all philosophy is by nature distortive of the biblical conceptual background. Knierim's ideas, however, did not seem to have won favour in mainstream Old Testament theology and he was taken to task by many (e.g. R. Murphy).

Another point to be made here is that it is impractical, given that philosophers of religion proper have normative concerns with contemporary beliefs and do not have the luxury to become exclusively concerned with a descriptive clarification of ancient Israelite religion for its own sake. Many have no training in biblical criticism, a prerequisite for any philosophical approach to the Hebrew Bible. If biblical scholars do not develop and engage in a descriptive philosophical approach to the text aimed at historical clarification, no-one will.

A fourteenth and final possible objection might come from those who concur with the claim that a philosophical approach is possible, but imagines it to be redundant. After all, other disciplines are already concerned with the Hebrew Bible and philosophical issues (some forms of biblical theology, systematic theology, Jewish and Christian philosophy of religion). However, whilst indeed many other disciplines discuss the kind of issues that philosophers of religion are interested in and with reference to the Hebrew Bible, none does so in a purely descriptive manner, in a way actually involving doing philosophical analysis, rather than merely hermeneutical meta-commentary (cf. Knierim 1995). Jewish philosophy and biblical theology may investigate related concerns like the nature of Yhwh, biblical theodicy or ethics, yet none is really concerned with purely descriptive philosophy of religion.

In addition, any possible overlapping with already extant agendas does not mean that a philosophical approach to Yahwism is redundant, for such overlapping is present in all subjects of all disciplines. Just because historians and sociologists share many common concerns does not render either superfluous, even when there is often little distinction between a historical sociology and a social history. Literary criticism in the study of the Hebrew Bible is not considered unnecessary just because some literary critics proper have at times written on the biblical text. So via analogy, just as biblical theology is not made redundant by overlapping discussions in historical, systematic and philosophical theology, so too a philosophical approach to ancient Israelite religion is not invalidated if some of its concerns overlap with those in biblical or systematic theology or Jewish philosophy.

\section{Conclusion}

In this article, I have identified and rebutted a number of popular objections to a philosophical approach in the study of ancient Israelite religion as represented in the Hebrew Bible. None of these can any longer be considered to hold water in any absolute sense. Although much in the critique of philosophical eisegesis carry within it a valid point of concern and was probably brought to the fore as 
a result of legitimate hermeneutical insights and historical consciousness, it should now be admitted that when used as generalisations they are fallacious. Given that they only carry any weight given certain essentialist presuppositions or views of the nature of the Hebrew Bible, of philosophy of religion and of biblical scholarship, they now need to be rethought in terms of absolute normativity. In some ways the 14 objections treated now seems so '20th century'. Perhaps we need to rethink relations between Athens and Jerusalem: times change.

\section{References}

Barr, J., 1966, Old and New in Interpretation: A Study of the Two Testaments, SCM Press, London.

Barr, J., 1999, The Concept of Biblical Theology: An Old Testament Perspective, Fortress Press, Philadelphia.

Barton, J., 1995, 'The Basis of Ethics in the Hebrew Bible', in D.A. Knight (ed.) Ethics and Politics in the Hebrew Bible, Semeia 66, pp. 11-22, Scholars' Press, Atlanta.

Brueggemann, W., 1997, Old Testament Theology: Testimony, Dispute, Advocacy, Fortress Press, Philadelphia.

Carroll, R.P., 1991, Wolf in the Sheepfold: The Bible as Problem for Christianity, SPCK, London.

Charlesworth, M.J., 2002, Philosophy of Religion - The Historic Approaches, new rev. edn., Macmillan, London.
Connolly, P. (ed.), 1999, Approaches to the Study of Religion, Continuum Books International, London.

Gerstenberger, E., 2002, Theologies in the Old Testament, Continuum International, London.

Hasel, G., 1985, Old Testament Theology: Basic Issues in the Current Debate, William B. Eerdmans, Grand Rapids.

Hebblethwaite, B., 2005, Philosophical Theology and Christian Doctrine, vol. 3, EPR Series, London, Wiley-Blackwell.

Knierim, R.P. 1995, The Task of Old Testament Theology: Method, Substance, Cases, William B. Eerdmans, Grand Rapids.

Morris, T.V., 2002, Our Idea of God: An Introduction to Philosophical Theology, Regent College Publishing, London.

Murphy, N., 1996, Beyond Liberalism and Fundamentalism: How Modern and Postmodern Philosophy Set The Theological Agenda, Continuum International Publishing Group, New York.

Orr, J., n.d., 'International Standard Bible Encyclopedia', Bible History, viewed 10 March 2010, from http://www.bible-history.com/isbe/P/PHILOSOPHY/

Preuss, H.D., 1996, Old Testament Theology, 2 vols., OTL, Westminster/John Knox, Louisville.

Smith, M., 2004, The Memoirs of God Memoirs of God: History, Memory and Experience of the Divine in Ancient Israel, Fortress Press, Augsburg.

Smith, M., 2008, God in Translation: Deities in Cross-Cultural Discourse in the Biblical World, FAT 57, Mohr-Siebeck, Tubingen.

Taliaferro, C., 2006, 'Philosophy of religion', in R.A. Segal (ed.), The Blackwell Companion to The Study of Religion, p. 123, Blackwell, Oxford.

Thiselton, A., 1980, The Two Horizons: New Testament Hermeneutics and Philosophical Description with Special Reference to Heidegger, Bultmann, Gadamer and Wittgenstein, William B Eerdmans, Grand Rapids.

Von Rad, G., 1962, Old Testament Theology: The Theology of Israel's Historical Traditions, vol. 1, Old Testament Library, Harper, Michigan 